\title{
Spirituality in Psychotherapy Settings: A Phenomenological Inquiry into the Experiences of Turkish Health Professionals
}

\author{
Halil Ekşi ${ }^{1}$ \\ Marmara University
}

\author{
Zeynep Takmaz ${ }^{2}$ \\ Marmara University
}

\author{
Selami Kardaş ${ }^{3}$ \\ Marmara University
}

\begin{abstract}
This study aims to explore the role of spirituality in psychotherapy using counselors' own experiences. A phenomenological approach was used to examine data from interviews completed by eight psychological counselors working in the counseling field in Istanbul, Turkey. Findings showed that counselors acknowledged the importance of discussing topics related to spirituality. Common reasons for engaging in spiritual discussions in treatment were outlined. Results suggest that developing skills and confidence to work with issues of spirituality is a complex and dynamic task.
\end{abstract}

\section{Keywords}

Spirituality in counseling $\bullet$ Spiritual therapeutic process $\bullet$ Counselor's approach to spirituality

\section{Psikoterapi Sürecinde Maneviyat: Türk Sağlık Çalışanlarının Deneyimleri Üzerine Fenomenolojik Bir Araştırma}

Öz

$\mathrm{Bu}$ çalışma danışmanların deneyimleri üzerinden psikoterapi sürecinde maneviyatın rolünü ortaya çıkarmak amacıyla yapılmıştır. Araştırmada İstanbul'da psikolojik danışmalık alanında hizmet veren 8 psikolojik danışman ile yapılan görüşmelerden alınan verileri incelemek için fenomenolojik (olgubilim) desen kullanılmıştır. Araştırma bulgularına göre psikolojik danışmanlar danışmanlık sürecinde maneviyata önem vermektedir ve maneviyatın sürece dâhil edilmesi gerektiğine yönelik birtakım nedenler belirtmişlerdir. Araştırma bulguları maneviyat ve maneviyatın getirileriyle çalışmak konusunda beceriler geliştirmenin kompleks ve dinamik yapıda olduğunu göstermektedir.

\section{Anahtar Kelimeler}

Danışmada maneviyat • Manevi terapötik süreç • Danışman’ın maneviyata yaklaşımı

\footnotetext{
* The paper is based on the master's thesis of the second author.

1 Department of Educational Sciences, Marmara University, Istanbul, Turkey. Email: halileksi@marmara.edu.tr

2 Correspondece to: Zeynep Takmaz, PhD Student, Marmara University, Department of Educational Sciences, Goztepe Campus, Kadikoy 34722, Istanbul, Turkey. Email: zeyneptakmaz@gmail.com

3 Department of Educational Sciences, Marmara University, Istanbul, Turkey. Email: selamikardas@gmail.com

Citation: Ekși, H., Takmaz, Z., \& Kardaș, S. (2016). Spirituality in psychotherapy settings: A phenomenological inquiry into the experiences of Turkish health professionals. Spiritual Psychology and Counseling, 1, 89-108. http://dx.doi.org/10.12738/spc.2016.1.0005
} 
Human rights movements, multiculturalism, sensitivity to cultural values, and technological advances have all contributed to the creation of a new world vision. Individual-oriented approaches in psychological counseling, quantitative measuring techniques, conscious human behaviors, and objective reality have influenced prevailing practices such as counseling approaches, sensitivity to social and cultural variations, and the use of qualitative methods and approaches that aim to recover the hidden properties of human behaviors and subjective reality (Karairmak \& Aydın, 2007).

According to Jung, a pioneer of spirituality, all human matters are spiritual, and that recovery is impossible without spiritual revival. Hence, touching issues related to spirituality is necessary to arrive at healing. Furthermore, Jung posited that considering intellectual and moral insights only is not enough; a spiritual point of view is indispensable to solve human dilemmas. Along with physical, emotional, and cognitive functioning, spiritual functioning is also essential (Stanard, Sandhu, \& Painter, 2000).

Nowadays, the concept of spirituality, which originates from the Latin word spiritus ("to breath," "to be alive," and more generally "to feel life"), is in the process of being redefined (Elkins, Hedstorm, Hughes, Leaf, \& Saunders, 1988). Studying the literature on spirituality, Tanyi (2002) stated that although spirituality has been discussed in multiple aspects, consensus about this topic has yet to be reached. The aspects of spirituality that have been studied include transcendence, mystery, commitment, purpose, divine power, and to be in connection with. Although the idea of spirituality has been discussed in the literature, such discussion has resulted in conceptual confusion (Düzgüner, 2013).

Indeed, researchers have yet to agree on definitions for the terms "religion" and "spirituality" (Richards \& Bergin, 2005). The literature shows that the concept of spirituality, previously related to religion, has begun to gain a broader perspective (Tanyi, 2002). On the one hand, the term "religious" means a connection with an institutionalized religion and a confirmation of theological doctrine or dogma. On the other hand, the term "spiritual" mostly refers to a connection to the transcendent, which is dissociated from organized religion for some (Sperry \& Shafranske, 2005). Such overlapping meanings make differentiating the two terms difficult, and yet these terms are recognized as distinct (Hage, Hopson, Siegel, Payton, \& DeFanti, 2006). In this regard, although spirituality and religion have been taken to have the same meaning, they are, in reality, different concepts. According to studies, the obvious criterion that most people use to differentiate the terms "religious experience" and "spiritual experience" is whether they happen in an institutional or an individual context. Most people consider themselves spiritual but not religious; such people also see themselves as being connected to God and holy things but not followers of an organized religion (Zinnabauer, Pargament, \& Scott, 1999). Thus, a person can be 
religious and spiritual, religious but not spiritual, spiritual but not religious, or neither religious nor spiritual (Worthington, Kurusu, McCullough, \& Sandage, 1996).

Since the ancient times, the concept of mental health remained inseparable with religion and spirituality in all societies. However, beginning in the 20th century, this view gave way to separated lenses of concepts. Religion and spirituality, previously addressed as a psychopathology by psychoanalytic theory and also excluded by behavioral theories that heavily focus on human behaviors, had left its mark in the historical process of psychological sciences as part of human nature and as a healing factor in the psychotherapy process with the effect of humanistic/existential theories and transpersonal movements.

Such subjects as religion and spirituality are not studied in psychological inquiries. The first reason for this is that psychology aims to establish itself as a strict science and, thus, it ignores or denies its religious and philosophical roots. The other reason is the prevalence of the views of proponents of clinical paradigms, such as Freud and Skinner, who have an undervalued and stereotyped vision of religion and spirituality (Wullf, 1997). However, these views began to change by the end of the 20th century, when the scientific aspect of psychology discovered new paradigms, such as positive psychology and eastern psychology, which have interests in subjects like religion and spirituality (Pargament \& Saunders, 2007). Positive psychology, which is the new focus of psychology, also underlines the importance of the relationship between religion and psychology (Tsang \& McCullough, 2003). Generally, psychology and science have appropriated spirituality and religion more toward the very end of the 20th century and used meticulous scientific methods, such as double-blind randomized clinical trials, to examine important questions related to the link between psychology and religion (Miller \& Thoresen, 2003).

Psychotherapeutic practices and training methods have different positions in the field of spirituality, which is part of human nature. Spirituality is considered an essential trait of humankind and one of the fundamental assistants guiding our existence in the universe. The extensive usage of spirituality in the psychotherapy field shows the complementary role of spirituality as a tool to understand the individual. Clients need to share their spiritual and religious needs as part of the psychotherapy experience. Furthermore, spiritual needs that are widely emphasized in Western culture motivate individuals to seek psychological counseling (Karairmak, 2004).

The influence of religious and spiritual behaviors and beliefs on both mental and physical health outcomes have an important effect on the integration of psychology and spirituality. In recent years, the associations among spirituality, religion, psychology, and science have been justified, and many studies about this integration have been conducted. Alongside the public, professionals have also supported this 
integration (Koening, McCullough, \& Larson, 2001). During recent years, many mental health professionals, including psychologists, have become interested in spirituality and religion, which they consider part of their professional work; such professionals are the ones who strive to look for ways to better integrate spirituality into their psychotherapy processes (O'Hanlon, 2006).

Whether therapists mention religious and spiritual subjects in psychotherapy settings is also an important issue. Some therapists believe that, although religious and spiritual interaction is important and beneficial, they must be able to perform such an intervention. Therefore, therapists must look for competencies they should possess to enable them to apply interventions effectively. For therapists, having sufficient background and information in religious and spiritual issues is a prerequisite to acquiring these tasks (Milevsky \& Eisenberg, 2012; Saroglou, 2002). Meanwhile, therapy clients are willing to talk about religion and spirituality, which they consider as an appropriate part of the psychotherapy process. Clients not only think that therapists' religious and spiritual views are related to their work, they also want therapists to share their experiences (Rose, Westefeld, \& Ansley, 2001; Walker, Worthington, Gartner, Gorsuch, \& Hanshew, 2011). In comparison, some therapists do not want to address spiritual and religious issues with clients, and this may stem from their avoidance of such issues. Moreover, not having competencies in discussing spiritual and religious issues can be considered another reason why therapists are reluctant to incorporate such issues into their therapies (Rose et al., 2001; Rosmarin, Green, Pirutinsky, \& McKay, 2013).

According to the results of a study conducted among American psychologists belonging to the American Psychological Association (APA, 2010), 60\% of their clients described their personal lives by using spiritual terms and by sharing them with the therapists; furthermore, one in six clients directly mentioned spiritual matters. Lukoff (1998) further reported that $72 \%$ of the clients spoke of religious and spiritual subjects in different times during their psychotherapy process. According to a Turkish study on religiosity and spirituality, a collaboration between the Presidency of Religious Affairs and the Turkish Statistical Institute, $64.9 \%$ of the respondents lived their lives completely in accordance with religious principles, $28.3 \%$ sometimes lived their lives based on the religious code, and $4.6 \%$ did not live in accordance with any religious code (Diyanet İşleri Başkanlığ 1,2014 ).

Intercultural transitions in psychology play an important role in the increasing interest in the link between religion and spirituality; furthermore, problems of religion and spirituality have been considered legitimate aspects of cultural diversity (Shafranske \& Malony, 1990). The ethical code of the APA, which emphasizes the growing diversity of religious and spiritual variables, states that "Psychologists are 
responsible for enabling their clients to speak of psychological functions and stress of their religious and spiritual beliefs and values, references and taboos which affects one's world perspective" (APA, 2010).

In addition, according to the ethical code of the American Counseling Association(ACA) (2014), it is necessary for counselors to accept these codes, which include the importance of spiritual leaders (Standard A.1.d.), support of spiritual needs as after life care (Standard A.9. a.1.), being in relation with spiritual self-care (Section C, Introduction), avoiding discrimination based on spirituality (Standard C.5.), and understanding the importance of spirituality in assessment process (Standard E.8.). Additionally, encouraging respect of clients' esteem and welfare is the basis of the ACA's ethical code, because considering the clients' religious and spiritual problems while counseling may increase the efficiency of counseling (Propst, 1996 as cited in Giordano \& Cashwell, 2014). Meanwhile, increasing the value of spirituality in the psychotherapy process has been found to affect the therapists' training. According to Kelly (1994), only $25 \%$ of psychological counselor training programs included spirituality, while Young, Cashwell, Wiggins-Frame, and Belaire (2002) found that this rate increased to 69\% eight years later. In 2012, this rate increased further to $84 \%$ (Dobmeier \& Reiner, 2012).

The Association for Spiritual, Ethical and Religious Values in Counseling developed and organized a total of 14 competencies to handle spiritual matters, categorizing these into six chapters (culture and world view, counselor self-awareness, human and spiritual development, communication, assessment, and diagnosis and treatment). These qualifications provide the minimum expectations for an efficient counseling process that incorporates spirituality. The 7 th requirement states that, "A professional counselor should respond to a client's interaction about his/her spirituality and religion with acceptance and sensitivity" (Cashwell \& Watts, 2010). However, many counseling students and counselors perceive such a requirement as an obstacle.

Therapists should reflect on clients' spiritual experiences in order to understand them completely. By doing so, they can be more respectful of the clients' religious beliefs. This may also help therapists understand whether their clients need spiritual interventions and, if they do, which ones will be beneficial to them. There is also a possibility that clients have spiritual anxiety; thus, they need to talk about it in the psychotherapy process to resolve this issue. Finally, therapists must understand whether clients' religious and spiritual beliefs are harmful to their mental health and if these may be used therapeutically (Richards \& Bergin, 2005). Curiously, although studies have shown that the association between psychology and religion is important and beneficial, some questions remain on whether the integration of psychology and religion is ethically, professionally, and scientifically hazardous (Sloan, Bagiella, \& Powell, 1998). 
One reason why therapists are reluctant to integrate spirituality in assessing a client's spirituality during a psychotherapy process is that the former may impose their own beliefs on the latter (Giordano \& Cashwell, 2014). Therefore, understanding the therapists' views, perceptions, and thoughts about spirituality in their own counseling processes is important. The current study aims to explore the role of spirituality in psychotherapy using counselors' own experiences.

\section{Method}

\section{Research Model}

This study is based on a methodology that uses qualitative research models to reveal how psychological counselors approach spiritual subjects and their opinions on this matter during the counseling process. In conducting qualitative research, a process that aims to reveal the perceptions and the cases in a realistic and holistic form, data are generally gathered through personal observations, interviews, document analysis, and so on (Creswell, 2012).

Qualitative methods are mostly used in the social sciences. Although there are other reasons, the qualitative methods are often used because of the complexity and obscurity of human interactions. Every individual has a unique set of behaviors, and this uniqueness makes it difficult to fully understand a person (Flick, 2002).

The current study was designed as a phenomenology model of qualitative research designs, which can help reveal how individuals live and perceive a phenomenon and give meaning to it (Goulding, 2005). The phenomenon investigated here involved the exploration of perceptions and approaches of psychological counselors in response to the discussions of spirituality in the counseling process.

\section{Participants}

Data sources for phenomenology research are individuals and groups who experience the phenomenon in question and express themselves accordingly. Participants are determined by interviews and field observations. The criterion sampling method is suitable for these kinds of studies, which have a limited number of participants owing to the length of interviews required (Creswell, 2012). The participants in the current study comprised of eight psychological counselors working in İstanbul, each of whom was selected using the criterion sampling method. The sampling criteria in this study included possession of a master's degree and at least five years of experience in the field. Psychological counselors who fit these criteria were selected by preliminary investigations and interviews. Participants of the sample group must have accumulated a significant amount of professional experience 
and possess good qualifications. The study aimed to work with counselors who used different approaches and psychological counseling practices.

\section{Data Collection Tool}

A questionnaire consisting of semi-structured and open-ended questions was used as the main data collection tool. Semi-structured interviews combined both questions with fixed answers and questions that enabled the researcher to discuss the subject thoroughly (Creswell, 2003).

In the process of questionnaire preparation, the related literature was studied, and preliminary interviews with psychological counselors were carried out. The questionnaire based on counselors' feedback was shared with seven professionals who were consulted for their opinions on the questions. Revisions were done on the questionnaire according the professionals' responses, after which a pilot interview was done with a psychological counselor. Finally, the questionnaire was revised after the pilot interview.

The questionnaire consisted of three sections. The first section contained questions about demographic information (gender, age, professional experience) and occupational information (the university from which they graduated, approaches they adopted, interest areas, and working hours). The second section informed the participants of the aims of the study, and the final section contained 23 questions relevant to the study's main purpose.

\section{Data Analysis and Interpretation}

Data were gathered from the interviews by transcribing, analyzing, and interpreting the voice recordings using the theme analysis method. In this method, a general conceptual structure was first established, and the obtained data were coded based on this conceptual structure. The codes were then grouped under definitive themes, in which the codes were grouped according to their common characteristics, and specific themes were arranged into sub-groups. Finally, explanations were made on the findings with regards the related literature and within the scope of cause and effect by using these specific themes, as shown in the sub-theme-categories relation chart.

\section{Findings and Discussion}

After coding the obtained data, five general themes were established: "involvement of spirituality in the counseling process," "effects of spirituality in the counseling process," "psychological counselors' approach to spirituality," "psychological counselors' opinions and feelings about spirituality in the counseling process," and "education programs and spirituality." These themes contained categories and some had sub-themes. 


\section{Involvement of Spirituality in the Counseling Process}

Nowadays, most professionals in the psychology and counseling areas have noticed that spirituality is no longer excluded from the science of psychology; in fact, contrary to this, the link between religion and spirituality can strengthen this branch of science (Weaver, 1998).

Opinions of the participants about the involvement of spirituality in the counseling process were grouped in two categories, namely, "by counselor" and "by client." According to the participants, the reason for the involvement of spirituality in counseling is because of the "clients' desire to reach awareness in personal spirituality, interest in transcendence, self-perception, existential questioning and search for meaning." One participant reported having a positive opinion about the involvement of spirituality by stating that "Ignoring the spiritual dimension of a client, passing over or excluding this aspect in treatment will not give desired results" (P6). Using spirituality as a coping strategy is also cited as another factor by a client who stated, "Counseling/therapy without spirituality cannot be possible."

Another reason to involve spirituality in the counseling process is the expectation of each client. Unless clients bring it up, counselors choose not to involve spirituality in the therapy because of the unquestionable nature of the subject. The reason behind this choice is the need to distinguish between psychological counselors and religious figures. "As [much] as I can, I do not ask these issues due to the possibility of their misusages" (P3). However, some other psychological counselors prefer to involve spirituality without clients' expectations. They make this choice to understand client's spiritual beliefs, values, and attitudes. In this way, they get to know the clients more thoroughly and explore fields they feel strongly about.

To gain familiarity with clients, the respondents mentioned both negative and positive opinions about obtaining information concerning clients' spiritual tendencies during both the first session and anamnesis. No common opinions are shared by participating psychological counselors. A similar study on the subject showed that therapists preferred not to bring up spirituality unless clients mentioned it or if the subject came up during interaction; however, in rare occasions, therapists included spirituality during the psychotherapy process. In that study, therapists also stated their aim, as they did not want to influence the client and make spirituality the main subject of counseling (Kellems, 2005). The reasons why therapists do not want to touch on religion and spirituality may include the complexity of these issues, lack of knowledge in terms of incorporating them into the session, and concerns about legal and ethical considerations (Gonsiorek, Richards, Pargament, \& McMinn, 2009). Other studies explain how spirituality has become an aspect of the therapeutic process. In these studies, the reasons behind the involvement of spirituality in the process are listed as 
follows: change of belief, guilt, anger/rebellion against God, inconsistencies between lifestyle and religion, and conflicts with one's values (Johnson, Hayes, \& Wade, 2007; Kellems, 2005; Zenkert, 2011).

\section{Effects of Spirituality on the Counseling Process}

There are two effects of spirituality on the counseling process, namely, positive and negative. One participant stressed the risk of the counselor imposing his/her own beliefs and values upon the client as a negative effect of the involvement of spirituality in the counseling process, stating that "Therapy is a sensitive field. You can easily get involved in one's inner world and counselor can also intrude client's inner world as a mother does to her child ... The danger here is the possibility of dictating your own belief to the client" (P5). While commenting positively by stating, "Individuals with religious believes tend to have lower anger and anxiety levels" another participant also said, "It can also have negative effects if psychological counselor forgets the importance of the limits while bringing in the spiritual matters in counseling process" (P7). Yet another participant expressed a positive thought (i.e., spirituality enables him to have deeper information about the client) and a negative thought (i.e., it cannot be easily predicted how client will be affected). The client specifically stated, "It is beneficial to understand the client when spoken. It gives information about [the] client's way of thinking and how he/she presents his/her beliefs. However, one time, I gave a spiritual book to my client [who] didn't like it (P3)."

Participants who emphasized the negative effects of spirituality in the counseling process presented an ethical code, citing the risk of counselors imposing their own beliefs and values onto their client as a reason for their opinion. More than one participant expressed that inexperienced counselors and those who lack proper education, in particular, may corrupt the process and the development of the client by crossing the line as a result of not being able to follow the boundaries carefully. Another interesting statement made by a participant is that the involvement of spirituality lengthens the process and interferes with the appropriate work that must be done on the main cause.

The literature about the usage of spiritual and religious tools suggests different points of views. For example, Shafranske (1996) (as cited in Shafranske, 2013), claimed that those who use spiritual and religious tools may consider the following three factors:( i) it is not a systematic and appropriate way according to clinicians, (ii) it is subject to a clinician's personal interpretation, and (iii) it can change with the involvement level of the clinician in open spiritual cases. On the one hand, every spiritual/religious commitment does not contribute to the psychological well-being of the client; on the other hand, according to meta-analyses, a relation exists between spiritual/religious devotion and reduced risk factors for individual's psychological 
health (Pargament, 2002). Therefore, such a commitment not only contributes to individuals' development of positive feelings by changing them to be better persons, this also makes them tougher, wiser, and more creative and virtuous individuals, enabling them to be psychically and psychologically healthier (Fredrickson, 2002 as cited in Shafranske, 2013).

Similar to those presented in the literature, findings in this study show that there are mostly positive comments on the effects of spirituality on the counseling process. In particular, the spirituality of clients has an important role in coping with and solving problems as well as a positive effect on client's perspective of life. In fact, each statement made by clients has been found important by all participants. Clients are also satisfied if the therapist is willing to discuss about their spiritual issues; meanwhile, when they develop negative reactions, the therapy may become ineffective. Therefore, incorporating spirituality into the therapy is important as it also fully immerses a client into the counseling process (Knox, Catlin, Casper, \& Schlosser, 2005).

\section{Psychological Counselor's Approach to Spirituality}

Three sub-themes are identified concerning the counselor's approach to spirituality, namely, "attitudes towards spirituality," "therapeutic goals of spirituality in counseling," and "methods counselors use concerning spirituality." The subcategories for "attitude towards spirituality" include spiritual expressions, the role of praying in counseling, suggestions of spiritual readings, giving information on spiritual subjects, recommending a spiritual institution, and sources of psychological counselor's approach to spirituality.

For the first theme, most of the participants stated that clients' comments should not be ignored or denied. The participants mentioned that they should listen to clients carefully and respectfully, and that they should be able to express themselves by using an agreeable language in order to maintain attunement with the client. Regarding this, P4 said, "I do listen as I always do. These shares tell a great deal about that individual... ignoring would be a waste of a precious material." In addition, P1 said, "I always accept the client as he/she is. I acknowledge his/her beliefs, which might be about world or religion. But I acknowledge his/her world view as it is anyway." Some other participants stated that spirituality must be kept separated from religion while dealing with spiritual statements. In comparison, another participant stated, "It would be more scientific to keep the secular view while dealing with spiritual statements."

All the participants respect the concept of praying, which is one of the spiritual experiences of a client. Although some participants chose not to give any negative response, some others stated that they use this process as a therapeutic instrument. For example, "I would ask the client how it feels. Is praying felt good? Then we 
speak about the process" (P2). Participant 3 also commented, "Yes, I would say amen (amin). I do believe this is cultural and sincere. Sometimes [a] client may talk about his/her prayers. Then I ask about why he/she might be praying like this. I can then examine if a client brings this up in therapy" (P3). Another point is the need to differentiate whether praying is spiritual or pathological. Regarding this, participant 3 said, "Of course, it is important how he/she prays. A bipolar patient who is constantly praying and speaking about religious matters is completely different from someone who has some existential questions about religion."

Furthermore, according to participants, omitting or excluding client's comments about spirituality is not acceptable; they believe that actions related to spirituality, such as praying, are allowable. All participants have a common opinion of and attitude toward this matter, even though they have different spiritual orientations and used varied approaches. Concerning therapeutic relation and trust, all participants regard a client's spirituality as a valuable thing; they see it as part of the client and choose to respect it.

Nearly all the participants stated that they would not suggest any spiritual readings as doing so would be appropriate. In this regard, participant 3 said, "Clients do not need me to recommend him/her a religious book. They expect different things." Meanwhile, according to participant 2, "This is too directive. First, it is not my field. But if the client says he/she needs to find himself/herself in religious extent more, then I could encourage." Furthermore, participant 4 said, "Any text I would directly suggest would not be a text the client would perceive neutrally anymore." In addition, participant 5, who has never suggested a book but is not against it said, "Some universal arguments can be used."

Participants who are more flexible towards recommending such a spiritual source stated that, first, understanding the client thoroughly and establishing a good connection with him/her should be regarded as preconditions, and various opinions about giving information on spiritual subjects are given by the psychological counselors. Some participants approve of and use spirituality in their counseling under the prior conditions. Meanwhile, there are others who completely avoid it.

According to the findings, the participants can be separated into three groups based on their approach to the idea of recommending a spiritual institution to a client. Participant 8 , who is against it said, "No. I did not recommend. It is up to the client. Religion is not something that can happen with someone, someone's will. It can be only with the individual's will." Participant 7, who is part of the group of counselors who made the recommendation said, "In some occasions, I did tell a client who had questions about his/her brief, to talk with a religious figure. Of course, I would review the answers they get from that figure, if I find them unreliable I would suggest other alternatives." 
Participant 6, who is in the group of counselors who encourage without recommending said, "... I may mention about the alternatives if a client states that he/she wants to go. But if he/she does not tell anything, I would not tell if a client needs or not."

Psychological counselors show a non-directing and non-recommending approach in spirituality, citing the notion that the counselor should remain neutral. However, they also expressed that they encourage clients to discuss spirituality when needed. Previous studies conducted in other countries reported different results. In some studies, therapists do intervene and comment in spiritual matters. For example, along with mostly indirect techniques, therapists suggested conducting spiritual readings to their clients, recommending spiritual institutions, and discussing spiritual matters during the counseling process (Johnson et al., 2007; Kellems, 2005; Zenkert, 2011). Therapists also believe that spirituality and religion play an important role in some clients' lives, and that these subjects might be related to the issues brought into the psychotherapy process by the latter. If therapists expound on the cognitive, unconscious dimensions of such topics, they may be able to help their clients by exploring the effects of religious and spiritual questioning; they therapists may also use these questionings in finding an effective solution (Kelley, 1995).

However, although some therapists are comfortable with spirituality and are more willing to discuss it, while other therapists have strict boundaries and are completely against it. The willingness to encourage clients to explore spirituality can be commonly seen between therapists. According to a study by Shafranske and Malony (1990), which they conducted among 1000 psychologists, 91\% of the participants evaluate religious background, $57 \%$ use religious concepts and language, $32 \%$ suggest religious books, and $7 \%$ pray together with the client.

In the current study, nearly all the participants approached this subject with their personal views, training and readings are built upon personal interests and thoughts, and no standard answers are deduced from approaches and findings. Participant 4, who criticized the counselors' approach said, "I think it is valuable. We did not see anything regarding religion in psychiatry education. I think all the examples of statements and approaches to this subject are bad. Those who ignore and those who exceed by losing their psychiatrist identity and creating ambiguity... I neither ignore nor try to prove anything."

Psychological counselors who participated in the study exhibited some spiritual objectives and goals that are parallel to those of the counseling process. These goals are mostly about using spiritual data in counseling and the contribution of this approach to the general goal than about a client's spiritual development and the resolution of his/her spiritual problems. The method, which is used by participating counselors, is grouped into two categories, namely, directly spiritual and indirectly 
spiritual. Although there are methods that aim to improve a client's spirituality, there are also methods that evolve with the involvement of spirituality and aim to control the process. Dream analysis and encouragement of expression are the most commonly used methods in this kind of method.

In a process that involves intense spirituality, most of the participants specified that goals related to spirituality have a more effective process. In addition to systematic goals or aims, there are also those that arise spontaneously. Of these, the most commonly expressed goal, which is also stated in other categories, is to use a client's spirituality to understand and familiarize oneself with the client as well as to distinguish between pathological and existential spirituality. According to a model described as implicit and explicit integration by Tan (1996), therapists use direct and indirect methods involving spirituality. Some previous studies reported similar results (Richards \& Potts, 1995).

\section{Thoughts and Feelings of Psychological Counselors}

Other factors that must be considered in the psychotherapy process are the therapist's feelings, thoughts, and transferences. According to the findings of the current study, psychological counselors who participated in this study care about their personal awareness of spirituality and try to improve themselves at that point. Regarding this insight, one participant stated, "My discipline keeps me from violating the client. I would rather let the client speak than my speaking too much and comment. Then, I use client's own words if I need to comment. Because he/she may misunderstand my own words" (P5). Another participant said, "Supervision is important. If a counselor does not get supervision, he/she can be inadequate and if he/she is not good enough, he/she cannot help the client" (P8). Another one said, "Well, I try to notice more and more. I constantly keep tracking of what client makes me feel" (P3).

There are risks that must be considered when counselors share their own spirituality with the client. One participant mentioned, "It can make the client feel inadequate. Therefore, we need to be very careful. [A] client should not exaggerate and we should not reveal and idealize ourselves" (P6). Although it is not ideal for a counselor to open himself/herself during counseling, a counselor reflects his/her personal spirituality in the counseling process whether consciously or unconsciously.

Most of the psychological counselors who participated in this study do not express discomfort about spiritual matters. Some counselors are conscious of their own spirituality because religious and spiritual matters are sensitive matters in our society. A study conducted by Zenkert (2011) among therapists, looked into the effects of therapists' own spirituality on the therapeutic process. According to this study, even though therapists try not to impose their own personal beliefs and values, it is 
impossible to conduct a psychotherapy process without a values-based interaction (Zenkert, 2011). In addition to religious therapists, secular therapists also incorporate spirituality into the therapeutic process (Shafranske, 2005). According to clients in both secular and religious settings, spirituality is an important ingredient in recovery, and they want to transfer spirituality into the therapeutic process as a positive influence (Arnold, Avants, Margolin, \& Marcotte, 2002; D’Souza, 2002; Larson \& Larson, 2003; Morrison, Clutter, Pritchett, \& Demmitt, 2009; Rose et al., 2001). In another study, most of therapists considered spirituality as an effective ingredient in the therapeutic process (Hickson, Housley, \& Wages, 2000). Therapists also reported that their spiritual and religious beliefs significantly affected the psychotherapy process (Bilgrave \& Deluty, 2002; Smith \& Orlinsky, 2004). The current study's findings also show that, although therapists try to be conscious of their own spirituality and not to project it to the process, they tend to use it to their advantage.

\section{Education Programs and Spirituality}

All the participants claimed that they did not obtain any counseling training programs that included spirituality topics while completing their undergraduate and master's degrees. Instead, they reported that only ethical courses provided them with ideas on how to handle this subject. Most of the counselors also did not obtain any training nor do they read papers about spirituality. Some participants, who do not have a specific education background about the topic, tend to criticize the system. One participant said, "I know the basic religious rituals and basic dynamics of obsessive compulsive disorder. I know religious and spiritual elements in our culture. A psychological counselor should have some ideas about these subjects around him/her" (P7).

In comparison to the above, others seemed to not have any problems with the education program and materials as they claim that it would not be important to prepare for the sincerity of spirituality, that is, it is impossible for a counselor to be perfect and that a counselor should only look into it when needed. Regarding this, one participant said, "I read scientific papers but didn't get any training. It already does not exist in Turkey. Nevertheless, I study religious psychology and sociology. I believe it does not matter if you are ready or not, if I don't know I can ask. It is okay to ask" (P4).

Although participants generally think that spirituality and counseling should be included in the education system, they advise that the educational programs should be prepared and given very carefully as the subject is very sensitive and open to abuse. Regarding this, one participant said, "Unfortunately, I believe it should not be included in [the] curriculum due to Turkey's current conditions, because, we tend to misuse everything and distort such things. If it wasn't for this, it would be something I support" (P4). Another participant finds that the education programs 
are insufficient, saying that "The education in Turkey is not sufficient, therefore I don't choose to be trained here" (PC5). In contrast, a participant who thinks that spirituality and counseling should be included in educational programs said, "I believe all the psychologists need to know and be familiar with religion and spirituality, psychological counseling cannot be performed without knowing the culture" (P6).

When asked about their knowledge and capabilities, the participating counselors stated that they did not receive any education regarding working with spirituality; some of them have not even read a paper on the subject. Some participants believed that it is not necessary to receive any education regarding spirituality. They expressed the opinion that spirituality is not within the realm of what a counselor should study formally; a counselor may look into it when needed, but it is impossible for one to master every aspect in order to accommodate the client in spiritual matters. Richard and Bergin (2005) explained how having religious and spiritual beliefs/thoughts may help therapists in these aspects. Their proposition is based on the following reasons: a) it helps one understand the world view of the client, thus allowing the therapist to better understand the client emphatically and work more sensitively with the client; b) it helps the therapist decide whether the religious/spiritual tendencies of the client are healthy and if they have any effects on the present problems; c) it helps the therapist decide whether it can be used as a resource in the process; d) it helps the therapist decide which spiritual instruments can be used in the process of helping clients, and e) it helps the therapist decide whether the client has doubts, concerns, or needs related to spirituality (Shafranske, 2005).

Research conducted in other countries also showed similar results. According to Shafranske and Gorsuch (1984) psychologists have little or no education on spirituality. Similar to this, another study conducted among 1,000 Californian psychologists revealed that only $19 \%$ of the participants received education and $53 \%$ thought that they were capable enough to work with spirituality (Shafranske \& Malony, 1990). Pate and High (1995) reported that religious and spiritual aspects only came up in just half of the counselor education programs they examined. Another study conducted among 1,000 clinical psychologists showed that although $83 \%$ never received education on spirituality, $34 \%$ felt capable of working with spirituality (Shafranske \& Malony, 1990). According to Ganje-Fling and McCarthy (1991), most of the participating psychologists they studied felt highly comfortable about spirituality. However, nearly all graduate and postgraduate training programs have yet to offer training for such an integration (Russell \& Yarhouse, 2006).

According to counselor education experts who participated in the study of Adams, Puig, Baggs, and Wolf (2015) the main barriers preventing the integration of religion and spirituality into counselor education are summed up by the lack of information, 
perceived relevance, and personal interest. These experts also recommended various strategies such as continuing education and heightened awareness of oneself and others, so that counselors can overcome this situation. In another study, participants who had no such spiritual education, expressed that the involvement of the therapist's own beliefs is inevitable; they also emphasized the need for greater sensitivity towards this subject (Lannert, 1991). In his study, Cournoyer (1992) also emphasized the lack of education, concerns about imposing personal values, and the need for more supervision.

Findings show that related subjects are covered by ethical codes. However, in terms of ethical codes, techniques for working with spirituality are not covered in the undergraduate level. Hence, participants suggested that education programs involve spirituality, and that these programs should include cultural studies and the integration of spirituality and psychological theories and methods. These programs, however, should not include dogmas and must not be religion-oriented. Some participants expressed that spirituality should not be included in educational programs. Although these participants accept the necessity, they believe this is not yet feasible given the current social structure and conditions in Turkey. Therefore, educational programs must be developed and systematized only by experts in spirituality and counseling.

\section{Conclusion}

This study aims to contribute new ideas about therapists' views on the integration of spirituality into the counseling process. This work also examined therapists' views on psychotherapy involved spirituality, assessing their practices related to working with spirituality during therapy; the therapist's feelings and thoughts in involving spirituality in the counseling process; and including spirituality in the education programs.

Based on the interviews completed by eight psychological counselors working in the counseling area, the findings of the research were scrutinized under the following themes; "involvement of spirituality in the counseling process," "effects of spirituality in the counseling process," "psychological counselors' approach to spirituality," "psychological counselors' opinions and feelings about spirituality in the counseling process," and "education programs and spirituality."

Findings showed that counselors acknowledged the importance of discussing topics related spirituality. Common reasons for engaging in spiritual discussions in treatment were also outlined. Counselors utilized a variety of techniques, including both direct and indirect practices, and were able to articulate specific goals for these discussions. The results of this study suggest that developing skills and confidence to work with issues of spirituality is a complex and dynamic task. This process entails a commitment on the part of the counselors-in-education to develop self-awareness and counseling skills so that they can perform their duties effectively. 


\section{References}

Adams, C. M., Puig, A., Baggs, A., \& Wolf, C. P. (2015). Integrating religion and spirituality into counselor education: Barriers and strategies. Counselor Education \& Supervision, 54, 44-56.

American Counseling Association. (2014). ACA code of ethics. Retrieved from http://www. counseling.org/resources/aca-code-of-ethics.pdf

American Psychological Association. (2010). Ethical principles of psychologists and code of conduct. Washington, DC: Author.

Arnold, R., Avants, S. K., Margolin, A., \& Marcotte, D. (2002). Patient attitudes concerning the inclusion of spirituality into addiction treatment. Journal of Substance Abuse Treatment, 23, 319-326.

Bilgrave, D. P., \& Deluty, R. H. (2002). Religious beliefs and political ideologies as predictors of psychotherapeutic orientations of clinical and counseling psychologists. Psychotherapy: Theory, Research, Practice, Training, 39, 245-260.

Cashwell, C. S., \& Watts, R. E. (2010). The new ASERVIC competencies for addressing spiritual and religious issues in counseling. Counseling and Values, 55, 2-5.

Cournoyer, A. A. (1992). The spiritual aspect of loss: A phenomenological exploration with psychotherapists (Doctoral dissertation, University of Massachusetts, Massachusetts). Retrieved from http://0-search.proquest.com.seyhan.library.boun.edu.tr/pqdtglobal

Creswell, J. W. (2003). Research design: qualitative, quantitative, and mixed methods approaches. California, CA: Sage.

Creswell, J. W. (2012). Educational research planning, conducting, and evaluating quantitative and qualitative research (4th ed.). Boston, MA: Pearson.

Diyanet İşleri Başkanlığı. (2014). Türkiye'de dini hayat araştırması [Research on religious life in Turkey]. Retrieved from https://serdargunes.files.wordpress.com/2013/08/tc3bcrkiyede-dini-hayat-arastirmasi-2014.pdf

D'Souza, R. (2002). Do patients expect psychiatrists to be interested in spiritual issues? Australasian Psychiatry, 10, 44-47.

Dobmeier, R. A., \& Reiner, S. M. (2012). Spirituality in the counselor education curriculum: A national survey of student perceptions. Counseling and Values, 52, 47-65.

Düzgüner, S. (2013). Maneviyat algısı ve diğerkamlıkla ilişkisi: Kan bağışı örneğinde Türkiye ve Amerika karşılaştırmalı nitel bir araştırma [Spiritual perception and its relation with empathy: a qualitative study on blood donation comparing Turkey and USA] (Doctoral dissertation, University of Erbakan, Konya, Turkey). Retrieved from https://tez.yok.gov.tr/UlusalTezMerkezi/

Elkins, D. N., Hedstorm, L. J., Hughes, L. L., Leaf, J. A., \& Saunders, C. (1988). Toward a humanistic-phenomenological spirituality. Journal of Humanistic Psychology, 28(4), 5-18.

Flick, U. (2002). An introduction to qualitative research (2nd ed.). London, UK: Sage.

Ganje-Fling, M. A., \& McCarthy, P. R. (1991). A comparative analysis of spiritual direction and psychotherapy. Journal of Psychology and Theology, 19(1), 103-117.

Giordano, A. L., \& Cashwell, C. S. (2014). Entering the sacred: using motivational interviewing to address spirituality in counseling. Counseling and Values. 59, 65-79.

Gonsiorek, J. C., Richards, P. S., Pargament, K. I., \& McMinn, M. R. (2009). Ethical challenges and opportunities at the edge: Incorporating spirituality and religion into psychotherapy. Professional Psychology: Research and Practice, 40, 385-395.

Goulding, C. (2005). Grounded theory, ethnography and phenomenology: A comparative analysis of three qualitative strategies for marketing research. European Journal of Marketing, 39(3), 294-308. 
Hage, S., Hopson, A., Siegel, M., Payton, G., \& DeFanti, E. (2006). Multicultural training in spirituality: An interdisciplinary review. Counseling and Values, 50, 217-234.

Hickson, J., Housley, W., \& Wages, D. (2000). Counselors' perceptions of spirituality in the therapeutic process. Counseling \& Values, 45, 58-67.

Johnson, C. V., Hayes, J. A., \& Wade, N. G. (2007). Psychotherapy with troubled spirits. Journal of Addictive Diseases, 15, 55-68.

Karaırmak, Ö. (2004). Tinsel anlayışın psikolojik danışmadaki rolü [The role of spiritual intellection on psychological counseling]. Türk Psikolojik Danışma ve Rehberlik Dergisi, $3(22), 45-55$.

Karaırmak, Ö., \& Aydın, G. (2007). Yapılandırmacı yaklaşım: Çağdaş psikolojik danışma anlayışını ve uygulamalarını biçimlendiren bir güç [Constructivist approach: A power forms contemporary psychological counseling intellections and applications]. Türk Psikolojik Danışma ve Rehberlik Dergisi, 27, 91-108.

Kellems, I. S., (2005). A survey of university counseling center therapists: working with clients who have religious/spiritual issues (Doctoral dissertation, University of Maryland, College Park). Retrieved from http://0-search.proquest.com.seyhan.library.boun.edu.tr/pqdtglobal

Kelley, E. W. Jr. (1995). Counselor values: A national Survey. Journal of Counseling \& Development, 73, 648-653.

Kelly, E. W. (1994). Counselor preparation: the role of religion and spirituality in counselor education: A national survey. Counselor Education and Supervision, 33, 227-237.

Knox, S., Catlin, L., Casper, M., \& Schlosser, L. Z. (2005). Addressing religion and spirituality in psychotherapy: Clients' perspectives. Psychotherapy Research, 15, 287-303.

Koenig, H. G., McCullough, M. E., \& Larson, D. B. (2001). Handbook of religion and health. New York, NY: Oxford University Press.

Lannert, J. L. (1991). Resistance and countertransference issues with religious and spiritual clients. Journal of Humanistic Psychology, 31, 68-76.

Larson, D. B., \& Larson, S. S. (2003). Spirituality's potential relevance to physical and emotional health: A brief review of quantitative research. Journal of Psychology \& Theology, 31, 37-51.

Lukoff, D. (1998). From spiritual emergency to spiritual problem: The transpersonal roots of the new DSM-IV category. Journal of Humanistic Psychology, 38(2), 21-50.

Milevsky, A., \& Eisenberg, M. (2012). Spiritually oriented treatment with Jewish clients: Meditative prayer and religious texts. Professional Psychology: Research and Practice, 43, 336-340.

Miller, W. R., \& Thoresen, C. E. (2003). Spirituality, religion and health: An emerging research field. American Psychologist, 58, 24-35.

Morrison, J. Q., Clutter, S. M., Pritchett, E. M., \& Demmitt, A. (2009). Perceptions of clients and counseling professionals regarding spirituality in counseling. Counseling and Values, $53,183-194$.

O'Hanlon, B. (2006). Pathways to spirituality: Connection, wholeness, and possibility for therapist and client. New York, NY: Norton.

Pargament, K. I. (2002). The bitter and the sweet: An evaluation of the costs and benefits of religiousness. Psychological Inquiry, 13(3), 168-181.

Pargament, K. I., \& Saunders, S. M. (2007). Introduction to the special issue on spirituality and psychotherapy. Journal of Clinical Psychology, 63, 903-907. 
Pate, R. H., \& High, H. J. (1995). The importance of client religious beliefs and practices in the education of counselors in CACREP accretited programs. Counseling and Values. 40, $2-5$.

Richards, P. S., \& Bergin, A. E. (2005). A spiritual strategy for counseling and psychotherapy (2nd ed.). Washington, DC: American Psychological Association.

Richards, P. S., \& Potts, R.W. (1995). Using spiritual interventions in psychotherapy: Practices, successes, failures, and ethical concerns of Mormon psychotherapists. Professional Psychology: Research and Practice, 26(2), 163-170.

Rose, E. M., Westefeld, J. S., \& Ansley, T. N. (2001). Spiritual issues in counseling: Clients' beliefs and preferences. Journal of Counseling Psychology, 48, 61-71.

Rosmarin, D. H., Green, D., Pirutinsky, S., \& McKay, D. (2013). Attitudes toward Spirituality/ Religion Among Members of the Association for Behavioral and Cognitive Therapies. Professional Psychology: Research and Practice, 44(6), 424-433.

Russell, S. R., \& Yarhouse, M. A. (2006). Training in religion/spirituality within APAaccredited psychology predoctoral internships. Professional Psychology: Research and Practice, 37(4), 430-436.

Saroglou, V. (2002). Religion and the five factors of personality: A meta-analytic review. Personality and Individual Differences, 32, 15-25.

Shafranske, E. P. (2005). Psychology of religion in clinical and counseling psychology. In R. F. Paloutzian \& C. L. Park (Eds.), Handbook of the psychology of religion and spirituality (pp. 496-514). New York, NY: Guilford.

Shafranske, E. P. (2013). Addressing religiousness and spirituality in psychotherapy: Advanced evidence-based practice. In R. F. Paloutzian, \& L.Crystal Park (Eds.), Handbook of the psychology of religion and spirituality (pp. 595-617). New York, NY: The Guilford Press.

Shafranske, E. P., \& Gorsuch, R. L. (1984). Factors associated with the perception of spirituality in psychotherapy. The Journal of Transpersonal Psychology, 16(2), 231-245.

Shafranske, E. P., \& Malony, H. N. (1990). Clinical psychologists' religious and spiritual orientations and their practice of psychotherapy. Psychotherapy: Theory, Research, Practice, Training, 27(1), 72-78.

Sloan, R. P., Bagiella, E., \& Powell, T. (1999). Religion, spirituality, and medicine. The Lancet, 353, 664-667.

Smith, D. P., \& Orlinsky, D. E. (2004). Religious and spiritual experience among psychotherapists. Psychotherapy: Theory, Research, Practice, Training, 41, 144-151.

Sperry, L., \& Shafranske, E. P. (2005). Spiritually oriented psychotherapy. Washington, DC: American Psychological Association.

Stanard, R. P., Sandhu, D. S., \& Painter, L. C. (2000), Assessment of Spirituality in Counseling. Journal of Counseling \& Development, 78, 204-210.

Tan, S. Y. (1996). Religion in clinical practice: Implicit and explicit integration. In E. P. Shafranske (Ed.), Religion and the clinical practice of psychology (pp. 365-387). Washington, DC: American Psychological Association.

Tanyi, R. A. (2002). Towards clarification of the meaning of spirituality. Journal of Advanced Nursing, 39(5), 500-509.

Tsang, J., \& McCullough, M. E. (2003). Measuring religious constructs: A hierarchical approach to construct organization and scale selection. In S. J. Lopez \& C. R. Snyder (Eds.), Positive psychological assessment: A handbook of models and measures (pp. 345360). Washington, DC: American Psychological Association. 
Walker, D. F., Worthington, E. L., Gartner, A. L., Gorsuch, R. L., \& Hanshew, E. (2011). Religious commitment and expectations about psychotherapy among Christian clients. Psychology of Religion and Spirituality, 3, 98-114.

Weaver, J. (Ed.). (1998). Native American religious identity: Unforgotten Gods. Maryknoll, NY: Orbis Books.

Worthington Jr. E. L., Kurusu, T. A., McCullough, M. E., \& Sandage, S. J. (1996). Empirical research on religion in counseling: A 10-year review and research prospectus. Psychological Bulletin, 119, 448-487.

Wullf, D. M. (1997). Psychology of religion: Classic and contemporary (2nd ed.). New York, NY: Wiley.

Young, J. S., Cashwell, C., Wiggins-Frame, M., \& Belaire, C. (2002). Spiritual and religious competencies: A national survey of CACREP-accredited programs. Counseling and Values, $47,22-33$.

Zenkert, R. (2011). Therapists' responses to the discussion of religion and spirituality in therapy: Working with a trauma vs. non-trauma population (Doctoral dissertation, Widener University, Chester). Retrieved from http://0-search.proquest.com.seyhan.library.boun. edu.tr/pqdtglobal

Zinnbauer, B, J., Pargament, K. I., \& Scott, A. B. (1999). The emerging meanings of religiousness and spirituality: Problems and prospects. Journal of Personality, 67, 889-919. 